\title{
First Report of Soft Rot by Pectobacterium carotovorum subsp. brasiliense on Amaranth in Korea
}

*Corresponding author

Tel: $+82-33-330-1920$

Fax: $+82-33-330-1590$

E-mail: jsnnimp@korea.kr

ORCID

https://orcid.org/0000-0001-7834-4303

Received October 13, 2018

Revised November 23, 2018

Accepted December 6, 2018

\author{
Samnyu Jee $\mathbb{D}^{*}$, Jang-Gyu Choi, Suyoung Hong, Young-Gyu Lee, and Min Kwon \\ Highland Agriculture Research Institute, National Institute of Crop Science, Rural Development \\ Administration, Pyeongchang 25342, Korea
}

\begin{abstract}
Amaranth has the potential for good materials related to nutrients and health benefits. There are several diseases of amaranth such as leaf blight, damping-off, and root rot. As a causal agent of soft rot disease, Pectobacterium spp. could infect various plant species. In this study, we isolated the bacterial pathogen causing soft rot of amaranth in South Korea. In Gangneung, Gangwon province during 2017, amaranth plants showed typical soft rot symptoms such as wilting, defoliation and odd smell. To isolate pathogen, the macerated tissues of contaminated amaranth were spread onto LB agar plates and purified by a single colony subculture. One $\mathrm{ml}$ bacterial suspension of a representative isolate was injected to the stem of five seedlings of 2-week-old amaranth with a needle. Ten mM magnesium sulfate solution was used as a negative control. 16S rDNA gene and recA gene were sequenced and compared with the reference sequences using the BLAST. In the phylogenetic tree based on $16 \mathrm{~S}$ rDNA gene and recA gene, GSA1 strain was grouped in Pcb.
\end{abstract}

Keywords: Amaranth, Pcb, Soft rot, South Korea
As one of the oldest crops, amaranth (Amaranthus spp.) is domesticated in the Andean region of Latin America about 8,000 years ago (Rastogi and Shukla, 2013). The amaranth belongs to the genus Amaranthus and family Chenopodiaceae, and is classified to three types of grain, vegetable and ornamental type (Caselato-Sousa and Amaya-Farfan, 2012; Pandey, 2013; Tang and Tsao, 2017). Amaranth is recognized as good materials related with nutrients, and has received attention in recent years because of their potential health benefits (Tang and Tsao, 2017). There are several diseases of amaranth such as leaf blight, damping-off, and root rot (Celine et al., 2013; Rastogi and Shukla, 2013). Pectobacterium spp. cause soft rot and blackleg on various hosts (Charkowski,

Research in Plant Disease

pISSN 1598-2262, elSSN 2233-9191

www.online-rpd.org
2018). New species had been classified in recent studies such as $P$. aroidearum, $P$. parmentieri, $P$. peruviense, and $P$. polaris (Dees et al., 2017; Khayi et al., 2016; Nabhan et al., 2013; Waleron et al., 2018). In this day, Pectobacterium spp. are considered as species complex because Pectobacterium species showed diverse characteristics. Of old collection of $P$. carotovorum subsp. carotovorum, several isolates were re-classified as P. carotovorum subsp. brasiliense (Pcb) in South Korea (Lee et al., 2014). In this study, we aimed to isolate and identify the soft rot pathogen of amaranth in South Korea and identify.

Showing typical symptoms of soft rot disease, amaranth (Amaranthus caudatus L.) plants were collected from Gangneung, Gangwon province during 2017. Wilting and defoliation were observed on amaranth plant (Fig. 1A). Inner part of stem had macerated tissue and foul smell (Fig. 1B). To isolate pathogen, partial stem of amaranth was surface-sterilized for 90 s in 1\% hypochlorite solution and rinsed in sterile distilled 


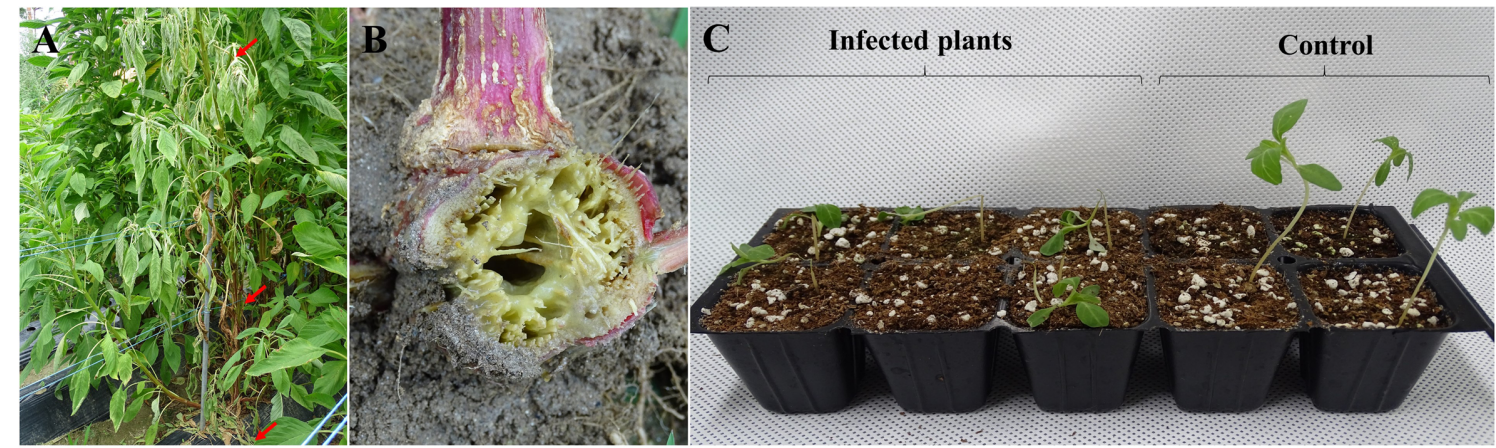

Fig. 1. Soft rot symptoms of amaranth caused by Pectobacterium carotovorum subsp. brasiliense on field (A, B), and artificial symptoms by inoculation (C). On third day after infection, infected plants showed soft rot symptoms and control was not affected by infection of $10 \mathrm{mM}$ $\mathrm{MgSO}_{4}$.

water. Samples were macerated in $1.5 \mathrm{ml}$ tube and were streaked on Luria-Bertani (LB) agar medium. The single colony was purified by subculture for two times. Bacterial isolates were stored at $-72^{\circ} \mathrm{C}$ with $20 \%$ glycerol. To test pathogenicity, a representative isolate was grown on $\mathrm{LB}$ agar for $16 \mathrm{~h}$ at $28^{\circ} \mathrm{C}$ and suspended in $10 \mathrm{mM}$ magnesium sulfate $\left(\mathrm{MgSO}_{4}\right)$ solution with an optical density of 0.5 at $600 \mathrm{~nm}$ wavelength using spectrophotometer (DS-11, DeNovix, USA). 1 ml bacterial suspension was injected to the stem of five seedlings of 2-week-old amaranth with a needle. As negative control, $1 \mathrm{ml}$ of $10 \mathrm{mM} \mathrm{MgSO}_{4}$ solution was inoculated to three seedlings of 2-week-old amaranth. Inoculated seedlings were incubated in a chamber with $28 \pm 1^{\circ} \mathrm{C}, 95 \%$ relative humidity for $16 \mathrm{~h}$. Inoculated amaranth seedlings were evaluated after disease symptom developed (Fig. 1C_left). The control plants didn't show the symptoms (Fig. 1C_right) of soft rot. To confirm Koch's postulates, the bacterium was re-isolated from amaranth seedling. To identify isolated bacterium, 16S rDNA gene and recombinase $A(r e c A)$ gene were sequenced by Macrogen, Inc. (Korea). Sequences of 16S rDNA (1,390 bp, Accession No. MH886389) and recA (668 bp) were compared with the reference sequences using the BLAST software in the GenBank database (http://www.ncbi.nlm.nih.gov/). With $16 \mathrm{~S}$ rDNA sequence of Pcb GSA1 strain, we found 99\% similarity to those of $P$. carotovorum. In the phylogenetic tree (Fig. 2), isolated bacterium was located in a group comprising a reference strain of Pcb. Based on symptoms, pathogenicity, and molecular analysis of $16 \mathrm{~S}$ rDNA and rec $A$, we concluded

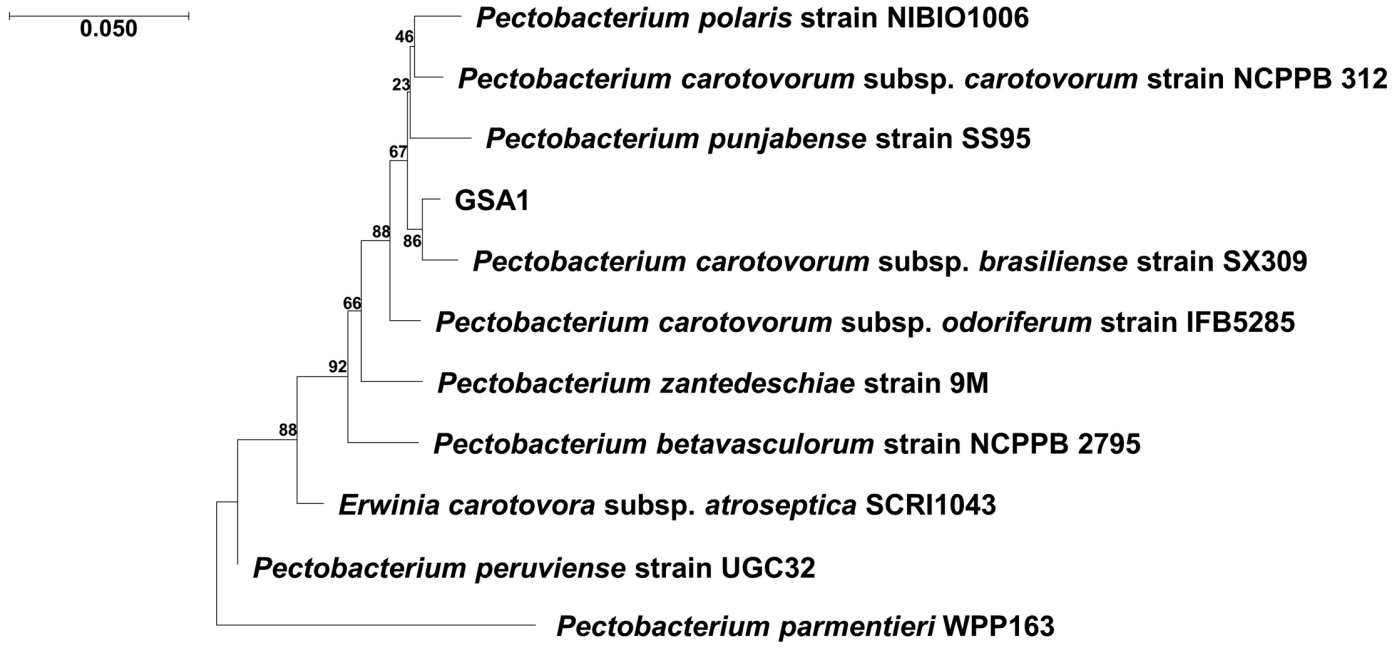

Fig. 2. Phylogenetic tree based on $16 \mathrm{~S}$ rDNA sequences and recombinase A sequences of Pectobacterium strains. DNA sequences from the NCBI database were aligned using ClustalW and phylogenetic trees were constructed using the neighbor-joining method and visualized with MEGA7. Isolated bacteria is GSA1. 
that the isolated bacterium from soft rot symptom of amaranth is Pcb. To our knowledge, this is the first report of soft rot disease by Pcb in amaranth plant.

\section{Conflicts of Interest}

No potential conflict of interest relevant to this article was reported.

\section{Acknowledgements}

This research was supported by the Rural Development Administration (RDA) fund PJ012108.

\section{References}

Caselato-Sousa, V. M. and Amaya-Farfán, J. 2012. State of knowledge on amaranth grain: A comprehensive review. J. Food Sci. 77: R93-R104.

Celine, V. A., Girija, V. K., Sreelathakumary, I. and Abdul Vahab, M. 2013. Selection of amaranth genotypes for resistance to Rhizoctonia solani. Int. J. Veget. Sci. 19: 157-163.

Charkowski, A. O. 2018. The changing face of bacterial soft-rot diseases. Annu. Rev. Phytopathol. 56: 269-288.

Dees, M. W., Lysøe, E., Rossmann, S., Perminow, J. and Brurberg, M.
B. 2017. Pectobacterium polaris sp. nov., isolated from potato (Solanum tuberosum). Int. J. Syst. Evol. Microbiol. 67: 5222-5229.

Khayi, S., Cigna, J., Chong, T. M., Quêtu-Laurent, A., Chan, K. G., Hélias, V. et al. 2016. Transfer of the potato plant isolates of Pectobacterium wasabiae to Pectobacterium parmentieri sp. nov. Int. J. Syst. Evol. Microbiol. 66: 5379-5383.

Lee, D. H., Kim, J. B., Lim, J. A., Han, S. W. and Heu, S. 2014. Genetic diversity of Pectobacterium carotovorum subsp. brasiliensis isolated in Korea. Plant Pathol. J. 30: 117-124.

Nabhan, S., De Boer, S. H., Maiss, E. and Wydra, K. 2013. Pectobacterium aroidearum sp. nov., a soft rot pathogen with preference for monocotyledonous plants. Int. J. Syst. Evol. Microbiol. 63 : 2520-2525.

Pandey, R. M. 2013. Biotechnological advances in amaranths species and their future outlook in crop improvement - A review. Recent Pat. DNA Gene Seq. 7: 179-186.

Rastogi, A. and Shukla, S. 2013. Amaranth: a new millennium crop of nutraceutical values. Crit. Rev. Food Sci. Nutr. 53: 109-125.

Tang, Y. and Tsao, R. 2017. Phytochemicals in quinoa and amaranth grains and their antioxidant, anti-inflammatory, and potential health beneficial effects: a review. Mol. Nutr. Food Res. 61: 1600767.

Waleron, M., Misztak, A., Waleron, M., Franczuk, M., Wielgomas, B. and Waleron, K. 2018. Transfer of Pectobacterium carotovorum subsp. carotovorum strains isolated from potatoes grown at high altitudes to Pectobacterium peruviense sp. nov. Syst. Appl. Microbiol. 41: 85-93. 